\title{
Examination of Orphaned Learners' Perspectives on Influence of Appreciative Project Design Orientation on Their Educational Achievements: The Case of Orphan Support Projects in Homa Bay County, Kenya
}

\author{
Abuya Isaac Odhiambo, PhD Candidate, Prof. Charles M. Rambo, Prof. Paul A. Odundo, Dr. \\ Raphael O. Nyonje
}

University of Nairobi

\begin{abstract}
It is estimated that 2.5 million of orphaned children live in Kenya, with Homa Bay County having the highest number of orphans, due to high incidences of adult AIDS related mortality. Available research suggests that orphaned learners have poor educational outcomes compared to non orphaned learners. To show commitments and support to the education of orphaned learners, the government of Kenya signed and supported the Declaration of the Right of the Child to Education, and has prioritized the education of orphaned learners, by investing financial and technical support towards the design and implementation of orphan support projects. It has been argued that the success of orphan support projects in promoting the education of orphaned learners depends on the extent to which these projects appreciate orphaned learners. However, despite the available evidence that projects that appreciate lead to improved educational outcomes learners, little research has examined the extent to which appreciative project design orientation influence orphaned learners' educational achievements. The objective of the study was to examine the perspectives of orphaned primary school learners enrolled in orphan support projects in Homa Bay County, Kenya on the influence of Appreciative project design orientation on their educational achievements. The cross-sectional study was grounded on pragmatism. A total of 363 primary school orphaned learners in classes 4-8 participated in the study. An Orphaned Learners' Questionnaire was used to collect data. To ensure validity and reliability of the research instruments, pilot testing was conducted in a community based orphan support project in the neigbouring Kisumu County. Cronbach alpha at $\alpha=0.05$ level of significance was used to compute the reliability coefficient of the pre-test instruments. Inferentially simple and multiple linear regression, and Pearson Correlation Coefficient models were used to determine the extent to which appreciative project design orientations influence orphaned learners' educational achievements, from the perspectives of the orphaned learners themselves. Tests of statistical assumptions were carried out before data analysis to avoid invalidation of statistical analysis. The hypothesis was tested at $\alpha=.05$ level of significance. The hypothesis $\mathrm{H}_{0} 1$ : Appreciative design orientation does not significantly influence orphaned learners' educational achievements in Homa Bay County was rejected since $(\mathrm{F}(10,353)=5.265 ; \mathrm{P}=0.000<0.05$, and so concluded that Appreciative project design orientation was significantly related to the orphaned learners' educational achievements. It is recommended that orphan support projects should integrate and intensify the use of appreciative project design orientation to ensure sustainable educational achievements for orphaned learners. Since this study delimited itself to orphaned learners' educational achievements, further research should be carried out to examine the extent to which appreciative project design orientation influence the educational achievements of orphaned learners' test scores in examinable subjects.
\end{abstract}

\section{Introduction}

It is estimated that 145 million children below 18 years have lost one or both parents (UNICEF, 2008b). Worldwide, 15 million school age children have been orphaned due to AIDS, with 11.6 million of these children orphaned in sub-
Saharan Africa alone orphaned due to AIDS. It is also estimated that 2.5 million of these orphaned children live in Kenya, with Homa Bay County having the highest number of orphans, due to high incidences of adult AIDS related mortality 
(UNICEF, 2008b). Available research suggests that orphaned learners have poor educational outcomes compared to non orphaned learners. Apart from the emotional and psychological effects that losing a parent can have on learners, there is clear evidence that orphaned learners do not attend school regularly, and are dropping out of school at higher rate than non orphaned children. Current knowledge suggests that when a parent dies, the amount of resources available for education decreases, as the cost of education becomes unaffordable, further compromising the rights of the orphaned learners to education. For learners whose parents have died as result of AIDS, the stigma and discrimination within the families, communities and schools may further exacerbate poor educational outcomes for such learners, manifested in irregular school attendance, limited participation in co-curricular activities, reduced motivation for home work, and may contribute to discipline referrals and grade repetition, or might out rightly lead to such learners dropping out school. Available research suggest that school attendance, participation in cocurricular activities, school discipline, home work completion and grade progression are critical indicators of educational achievements, and that these indicators positively influence performance in examinations.

Education is a basic human right for all children, including orphans, as recognised in the Convention on the Rights of the Child. It has been argued that a child who has access to quality primary education has a better chance in life. Basic quality education is also critically important to orphaned learners' social integration and psycho-social well being. Access to quality and sustainable basic education at the primary school level helps orphaned learners affected by the trauma of parental death to regain a sense of normalcy and to recover from the psychosocial impacts of their experiences and disrupted lives. As well as benefiting individuals, education benefits whole nations as a major instrument for social and economic development. Particularly at the basic level, education is a major contributor to the reduction of poverty. Education increases labour productivity, improves health, and enables people to participate fully in the economy and the development of their societies. Poor educational outcomes for orphaned learners compromises the orphaned learners' quality of life, productivity and competitiveness in the labour market, thus further reinforcing the disadvantage of such orphaned learners.

To show commitments and support to the education of orphans, Kenya signed and supported the Declaration of the Right of the Child to Education, and has prioritized the education of orphaned learners, by investing financial and technical support towards the design and implementation of orphan support projects. It has been argued that the success of orphan support projects depends on the extent to which they appreciate, empower, include and engage orphaned learners and the extent to which they promote the education of orphaned learners. The psychological and physical trauma following parental death, may affect the self esteem of these orphaned learners. These learners are likely to feel unappreciated, disempowered, excluded and disengaged in the learning process. As a result, for the orphan support projects to function effectively and to deliver services to the orphaned learners, the projects have to appreciate the challenges and diversity of orphaned learners, and must ensure that their policies and services are inclusive, empowering and should promote the engagement of the orphaned learners in the learning process.

Appreciative project design orientation, conceptualised as project design approach that appreciates, recognises and positively affirms children (Shier, 2001), is believed to have beneficial influence on a wide range of educational outcomes amongst orphaned learners (UNICEF, 2008b). Orphaned learners in Kenya do not attend school regularly, compared to non orphaned pupils in the country (Evans and Miguel, 2007), since the death of a parent or parents adversely affects the support that these children could have received from their parents. The stigmatization and discrimination of orphaned learners, and the poor educational achievements among orphaned learners in Kenya led to calls for appreciative orphan support projects ((UNICEF, $2008 \mathrm{~b}$ ). The critical role that appreciation plays in the educational achievements of learners was demonstrated by Bergmark and Alerby (2008) in their phenomenological study of the lived experiences of learners in Swedish secondary schools with ethical situations. The study found that appreciative educational environments characterised by healthy and positively affirming relationships between the teachers and the learners improved the speech and action and power among the learners, with demonstrated positive ethical 
decision making among the students which led to improved educational outcomes for the learners. This study confirmed the positive effective of appreciation and positive relationships between learners: appreciation of learners and positive affirmation of the learners lead to improved ethical decision making and improved perception that the learners that they are in control of their learning.

\section{Statement of The Problem}

It is estimated that about 2.5 million learners in Kenya have been orphaned by AIDS. Homa Bay County has the highest HIV prevalence, adult related AIDS related mortality and AIDS orphaned learners orphaned in Kenya. AIDS is a highly stigmatized condition and learners believed to have been orphaned by AIDS are more stigmatised and discriminated against. The stigmatization and discrimination of learners' presumed to have been orphaned by AIDS, adversely affect the orphaned learners' educational achievements. Due to the stigmatization and discrimination, learners presumed to have been orphaned by AIDS are more likely not to attend school, less likely to participate in co-curricular activities, more likely to repeat class, are likely to have low motivation to do home work and may engage in socially undesirable behaviours like drug taking and engaging in risky sexual behaviours, with adverse effects and consequences on the learners' human capital development, competiveness and employability.

The reduced human capital development, competitiveness and employability among orphaned learners with poor educational outcomes may exacerbate the orphaned learners' risks and vulnerability, thus sustaining the vicious cycle of poverty among the orphaned learners. Such orphaned learners are more likely than their non orphaned peers to engage in risky behaviours that may predispose them to the risk of HIV and AIDS, leading to high morbidity and increased mortality among the orphaned learners, with negative impacts on economy, the society and the nation as a whole. The poor human capital development among orphaned learners may put further strain on Kenya's economy, thus increasing further the cost of orphan support projects.

It has been argued that orphaned learners' educational achievements may be improved through cost effective project design orientations that appreciate the orphaned learners. It is believed that learners, who are appreciated, are likely to attend school regularly, actively participate in cocurricular activities, be more disciplined and do home work regularly, thus improving their overall educational achievements. Improving the educational achievements among orphaned learners by investing in appreciative project design orientation is cost effective, and is likely to reduce the cost of providing educational support for orphaned learners in the country, in the face of dwindling government and donor support for orphan support projects.

The available evidence on the influence of appreciative project design orientation has been conducted in non project settings with nonorphaned learners. As the support from donors and governments for orphan support projects in Kenya face uncertain future due to high inflation and donor fatigue, it has been argued that appreciation may improve orphaned learners' educational achievements. However, no known studies have been conducted in orphan support projects to examine the extent to which appreciative project design orientations influence orphaned learners' educational achievements.

\section{Objective of The Study}

The objective of the study was to examine the perspectives of orphaned primary school learners enrolled in orphan support projects in Homa Bay County, Kenya on the influence of appreciative project design orientation on their educational achievements.

\section{Research Hypothesis}

The study tested only one null hypothesis: $\mathrm{H}_{0} 1$ : Appreciative Project design orientation does not significantly influence orphaned learners' educational achievements.

\section{Review of Related Literature}

This section reviews the empirical literature on the influence of appreciative project design orientation and learners' educational achievements.

\section{The Concept of Appreciative Project Design Orientation}

This study adopted the definition of project design orientations as project design approaches and methods that appreciate vulnerable children thereby reinforcing their active participation in the development of projects and services meant for them (Shier, 2001). Such project for vulnerable children must ensure that the children are listened to, supported in expressing their views, and are involved in project decision making processes and 
also share power and responsibility for decisionmaking (Shier, 2001). Such projects not only appreciate and value the contributions and views of the children, but also positively affirm the children and their views and encourage their participation in the design of projects and services for vulnerable children.

Appreciative project design orientation, conceptualised as project design approach that appreciates, recognises and positively affirms orphaned learners (Shier, 2001), is believed to have beneficial influence on a wide range of educational outcomes amongst orphaned learners(Shier, 2001; UNICEF, 2008b). Such project designs for vulnerable children must ensure that the children are listened to, supported in expressing their views, their views must be taken into account, are involved in project decision making processes and also share power and responsibility for decision-making (Shier, 2001). Such projects are characterized by their appreciative, empowering, inclusive and engaging design orientations. Accordingly, such projects not only appreciate and value the contributions and views of the children, but also positively affirm the children and their views and encourage their participation in the design of projects and services for vulnerable children.

However, other scholars argue that project design orientations prevalent in educational support projects for vulnerable children are heavily stereotyping (Valencia, 2010). These scholars argue that the stereotyping and labelling of disadvantaged learners reinforces feelings of powerlessness and hopelessness, thereby reducing the capacity of vulnerable children to take control of their destiny, and eventually diminish the children's capacity to make own decisions ( Gorski, 2010). These scholars further posit that the biggest threat to vulnerable children's autonomy may come from interventions and service providers who fail to meaningfully involve children, and instead make all the decisions on their behalf (Valencia, 2010 and Gorski, 2010).

There is emerging evidence that appreciative projects foster and improve participation of disadvantaged and vulnerable learners, which lead to improved educational achievements and learning outcomes for these learners(Shier, 2001, Bergmark and Alerby, 2008; Dutcher, et al., 2016; Powers, et al., 2016; Marie , 2016; Abildsnes et al., 2015). Shier's (2001) pioneering paper on participation of children in the learning process, found that projects that foster and sustain the participation of children in educational activities are characterised by the way they appreciate and recognise the children as equal and active participants in programming. In his estimation, disadvantaged and vulnerable children have low self esteem and one of the critical means through their participation can be improved is by appreciating and recognising them as active participants.

\section{Appreciative Design Orientation and Learners' Educational Achievements}

The critical role that appreciation plays in the educational achievements of learners was also demonstrated by Bergmark and Alerby (2008) in their phenomenological study of the lived experiences of learners in Swedish secondary schools with ethical situations. The study found that appreciative educational environments characterised by healthy and positively affirming relationships between the teachers and the learners improved the speech and action and power among the learners, with demonstrated positive ethical decision making among the students which led to improved educational outcomes for the learners. This study confirmed the positive effective of appreciation and positive relationships between learners: appreciation of learners and positive affirmation of the learners lead to improved ethical decision making and improved perception that the learners that they are in control of their learning.

The positive influence of appreciation and recognition on the educational achievements of learners was also demonstrated in a study by Abildsnes et al., (2015). The study found that the positive thoughts among teachers and nurses on the capability of learners significantly improved the participation of the learners in physical education and also in the class. The study was conducted to explore the effects of positive thoughts of physical education teachers and school nurses on participation of learners in physical education and their participation in class. The appreciation and the positive affirmation of the learners, who had hitherto been perceived as unable, fostered and improved the self esteem of the learners, which led to their success in both physical education ( which some had thought the learners could not manage) and their improved participation in the class. This study confirmed the beneficial effects of appreciation and recognition on learners' educational achievements. 
Experimental studies have also confirmed the positive effects of appreciation on the educational achievements of learners. For instance, an experimental study by Dutcher, et al., (2016), on the effects of appreciation and positive affirmations of learners, found that appreciating learners and believing in the capacity to be successful even in difficult tasks, trigger physiological and neural reactions that foster and enhance the self esteem of learners and reinforcing their belief in their capability. This experimental study among college students reaffirmed the beneficial positive effects of appreciation and positive affirmation on learners. This study recommended that educational interventions must take into consideration the critical role that appreciation and positive affirmations play in the educational outcomes of learners.

In another experimental study that tested the effects of appreciation on leaners, Powers, et al., (2016) found that positive affirmations of the values of African American seventh graders triggered ecological effects that benefited their entire class rooms. African American $7^{\text {th }}$ graders whose racial and family values were appreciated and positively affirmed, improved in their performance in the classrooms, compared to the control arms of seventh graders whose racial and family values were stereotyped, and ridiculed. Seventh graders who whose racial and family values were appreciated and positively affirmed by the teachers, had high self esteem scores, related better with their teachers and peers and their class performance improved. However, the seventh graders in the control arm of the study whose racial and family values were stereotyped, ridiculed and condemned had reduced self esteem, related poorly with teachers and their peers and generally performed poorly in the class. This study reinforces the critical role that appreciation and positive affirmation play in the educational achievements of learners from disadvantaged and vulnerable families, backgrounds and communities.

The beneficial effects of appreciation and positive feedback on the educational achievements of learners were also investigated by Marie (2016). The researcher found that learners who valued being appreciated and receiving positive feedback had higher educational achievement scores. The researcher, like the others reviewed in this section, found that appreciating learners and providing them with timely feedback, and had a positive effect on their self esteem and belief about their ability. The result of this and other studies, call for integrating appreciative approaches in the design of educational projects that target disadvantaged and vulnerable learners like orphans.

\section{Learners' Educational Achievements}

School attendance is a critical measure and indicator of educational achievement among orphaned learners. This is because, school attendance affects the other measures and indicators of educational achievements, including learners' participation in co-curricular activities, learners' grade progression, discipline of learners and home work. Learners who attend school regularly are more likely to perform well in class and or school examinations, are more likely to be disciplined (since undisciplined learners are likely to infringe on the school rules and regulations thereby being suspended), are more likely to participate in school activities like games and related activities and are more likely to do and submit the home work in time.

Empirical studies have documented the factors that influence learners' school attendance. Recent empirical studies have documented the effect of appreciation and recognition on learners' school attendance. The way learners are appreciated and recognised by having their scholastic needs like payment of school fees and related levies in time has an effect on the ability to attend or not attend school (Posso and Feeny, 2016). In a study on the factors that affect learners' school attendance in Melanesia, the study found that delays in paying school fees and older learners, affected the older learners' school attendance. The failure to appreciate and recognise the learning challenges of older learners by preferring younger learners over the older ones, had significant effect on the older learners' school attendance. The delays and at times failure to pay the fees and related school levies, affected the older learners as they felt unrecognised and discriminated against them.

The care that is provided to learners has been found to have significant positive effect on learners' school attendance (Cabus and Witte, 2015). The study investigated the effects of improved care and school attendance interventions, on learners' school attendance. The study found that improved care for and empathetic interactions between social workers and disadvantaged and at risk learners, improved the school attendance rates among the learners. The study conceptualised disadvantaged and at-risk 
learners, as those with higher odds of missing and dropping out of school. The increased school and home visits of the at risk learners by the social workers and the targeted school attendance interventions with schools, had significant positive effects on school attendance among the learners.

Participation in co-curricular activities like games, sports, creative arts (drama and singing), debating among others is also an important measure and indicator of learners' educational achievements. Learners who feel appreciated and recognised, and who are perceived to be competent not only actively participate in the co-curricular activities but also improve their performance in a wide range of subjects and educational activities (Belton, Prior, Wicke and Woods, 2017). In a cross-sectional study that examined the effects of learners' perceived self competence, self esteem on participation on extra-curricular activities among 174 learners aged 12-15 years in four schools, the study found that learners who had high perception of self competence, who reported appreciated and recognised by their teachers for their competence, reported higher scores on selfesteem and also had improved performance in a number class based subjects.

Grade and class progression (promotion) is an important measure and indicator of learners' educational achievements. While the government has a policy that all learners in primary school should not repeat any class, class repetition is a reality for a number of learners in the country. The focus on passing examinations in a few examinable subjects has been the focus of Kenya's educational system. Consequently, learners who fail to meet the pass mark have been forced to repeat classes. The extent to which grade progression and grade repetition affect learners' academic achievements and psycho-social adjustment was investigated by Klapproth, et al., (2016). The study found that retaining learners did not have significant effect on their performance in their retained classes. The retained learners felt disengaged from the learning processes and did not show significant improvement in performance in their retained classes. The study also found that retained learners had low self-esteem and reduced sense of self-efficacy, compared to the learners who were promoted. A study conducted by Taniguchi (2015) among learners in grades 5 and 7 in rural Malawi had similar findings.

Discipline of learners is an important measure and indicator of educational achievements. Learners who are disciplined are more likely than their non disciplined peers to attend school regularly, participate in co-curricular activities, get promoted to the next class, and do and submit their home work. Discipline is the glue that fosters and cements positive relationship between learners and their teachers. Studies have demonstrated the relationship between teachers' attitude towards learners and the discipline levels among learners. In a study by Moye (2015) among 500 secondary school learners in Ondo State in Nigeria on learners' indiscipline and primary school teachers' attitude, the researcher found that the lackluster and the non caring attitude of the teachers adversely affected the discipline levels among the learners. The learners did not feel appreciated and recognised by the teachers, their views were not seen as important and they were felt least involved in the decisions that the primary school teachers made.

Completion and submission of the daily home work assigned to learners by subject teachers is an important measure and indicator of learners' educational achievement. Learners who do and submit their home work as instructed by their subject teachers are more likely to have a better mastery of the subject contents, and are more likely to perform well in the assigned subjects, than the learners who fail to do and submit their home work assignments to the subject teachers for marking and correction. A number of factors have been found to affect learners' home work. Teachers' home work follow up practices including checking home work completion, how the learners have answered the questions assigned to them for home work and the way the teachers' grade and comments on the learners' home work indicate the teachers' interest in and appreciation of the efforts that the learners have put in the assigned home work. In a study by Rosario, et al., (2015) on the effects of teachers' home work follow-up practices among 26 subject teachers, the study found that positive follow up practices in the form of showing genuine interest the learners' home work, the use of positive comments and recognition of the learners' efforts, had significant positive effect on learners' performance in the assigned subjects.

Understanding, appreciating and recognizing the problems that learners experience during home work and providing autonomy to the learners in their home work has been shown to have significant influence on home work (Eunsook, 
Min and Yun, 2011). In a cross-sectional survey of 268 tenth grade learners and their mathematics and English by teachers in a Chinese school, the study found that the learners who were unfavourably rated by their teachers had difficulties with their home work and had negative attitude towards the English and the mathematics home work assigned to them. The study's finding point to the importance of understanding, appreciating and recognizing the challenges that learners experience with their home work.

\section{Theoretical Framework}

The study was guided by the Theory of Change (ToC) model and the Theory of Participatory Design.

\section{Theory of Change (Toc) Model}

This study was guided by the Theory of Change (ToC) which is a framework for designing projects aimed at providing solutions to complex social problems. The theory of change requires the involvement of all project stakeholders and agreeing on the design issues and the outcomes that the project should address (Anderson (2005). The inclusive nature of the theory of change makes it particularly relevant for the study since inclusive design orientation is one of the critical variables that the study investigates. The theory of change makes assumptions that complex social issues that affect the community can be effectively addressed when all the project stakeholders appreciate the views and perspectives of project beneficiaries through an inclusive dialogue process. The outcomes that are desired by the project must be discussed by all the stakeholders and consensus built around expected outcomes before any intervention is designed.

According to Vogel (2012) appreciating the different perspectives of project stakeholders before and after the design of community based projects is an important component of the theory of change model. Identifying and involving stakeholders in appropriate ways in the design of the project is essential to strengthen the impact potential of projects and interventions that target vulnerable populations and communities (Vogel, 2012). Using theory of change can be a helpful way to structure discussions with stakeholders about their perspectives on the issues, their priorities and to develop an understanding of the opportunities for design to influence positive and sustainable project outcomes.
The theory of change argues that the views of all project stakeholders should be included before and after the design of the project to ensure sustainable solutions to complex social issues. The inclusive and participatory processes that are advocated by the theory of change are believed lead to project outcomes that are owned by all the stakeholders. Vogel's (2012) position on the importance of appreciating the different views and perspectives of project stakeholders is relevant to this study, since one of the objectives of the study is to investigate the extent to which appreciative design orientation in orphan support projects affect orphaned learners. The theory of change is empowering since it integrates empowerment approaches for social change and participatory approaches in the development of projects targeting vulnerable populations and communities (James, 2011). The view that the theory of change integrates empowering approaches is relevant for this study since empowering orientation is one of the variables investigated in the study.

\section{Theory of Participatory Design}

The study was also grounded on the Theory of Participatory Design. The theory posits that project beneficiaries must be involved in the design of the projects that target them, either as informants or as co-designers (Greenbaum and Kyng, 1991). According to the theory, project beneficiaries have a democratic right to be included in the design of what affects them, since including them in design activities results in better and more efficient, usable projects and services. Participatory designs give value to both human and operational project improvements and that it produces empowered, enabled, valued, fulfilled project beneficiaries and projects that produce better results (Ehn, 1993). Empowerment, inclusion, involvement and appreciation of the diversity and views of the project users are critical elements of participatory project designs. In participatory designs, project designers and project beneficiaries work together to explore assumptions, alternatives, spaces and possibilities based on their combined knowledge, and experiences.

The assumption made by this theory was relevant to this study since inclusive design orientation was one of the variables examined in the study. The theory was also relevant since it links project design to outcomes for beneficiaries. In this study, an attempt was made to examine the influence of project design on the educational outcomes for 
orphaned learners. The theory was relevant to the study since empowerment, inclusion; involvement and appreciation were the independent variables that the study investigates. Furthermore, participatory design theory provided a framework for appreciating the diversity and views of both the project designers and project users that lead to better outcomes for project beneficiaries, according to Greenbaum and Kyng (1991). The theoretical basis for participatory design is the equal participation of project designers and the targeted project beneficiaries, in an environment of respect, consultation and shared responsibilities. The theory was relevant since it focuses on community based orphan support projects that mostly target vulnerable orphaned learners.

\section{Research Methodology}

Cross-sectional research design was adopted in this study. Cross sectional design is based on observations made at one point in time (Kothari (1985). Cross-sectional design collects data in a single point in time from a sample drawn from a cross section of the population. The data was collected in a single point among orphaned learners. The diverse geographical locations of the orphan support projects and target population made cross-sectional design appropriate for this study. The sample size for this study was drawn from a target population of 7043 primary school orphaned learners in class 4 to class 8 supported by enrolled by 20 community-based orphan support projects in Homa Bay County, Kenya. Using Krecie and Morgan (1970) sample estimation table, a sample of 363 orphaned learners was deemed to be sufficient for this study. Proportionate stratified random sampling was used get a proportionate ratio of orphaned learners in the targeted classes. Proportionate sampling procedure was appropriate for the study since it ensured that the different sub-groups of orphaned learners (paternal, maternal and double orphaned learners in different classes from different orphan support projects).

The main instrument for data collection in this study was a self administered Orphaned Learners' Questionnaire. The questionnaire had three sections. Section A was on the demographic profiles of the orphaned learners, Section B: Sought had ten statements on Appreciative Project Design Orientation, $\mathrm{C}$ sought information on Orphaned Learners' Educational Achievements.
The ten statements on Sections B and C of the questionnaire used positively and negatively worded items as recommended by Williams (1974), Numally (1978) Baumgertner and Steenkemp (2001), Podsakoff, et al., (2003) and Weijters and Baumgartner (2012). These authorities argued that the use of positively and negatively worded statements in a questionnaire minimise bias because such items reduce speed and promote cognitive reasoning in the subjects.

The section on Appreciative Project Design Orientation (ADO) contained five positively worded statements and five negatively worded statements to determine the extent to which the orphaned learners agreed with the appreciative project design orientation statements. The Appreciative Project Design Orientation (ADO) statements were. ADO1: The orphaned learners are motivated by the project/ADO2: The orphaned learners are not motivated by the projects; ADO3: The orphaned learners are appreciated by the project/ADO4: The orphaned learners are not motivated by the project; ADO5: The orphaned learners are encouraged by the project/ ADO6: The orphaned learners are not encouraged by the project; ADO7: The orphaned learners are praised by the project/ ADO8: The orphaned learners are not praised by the project; ADO9: The orphaned learners are valued by the project/ADO10: The orphaned learners are not valued by the project. Each of the statements had a 5 Likert scale ranging from Strongly Disagree $(\mathrm{SD})=1$; Disagree $(\mathrm{D})=2$; Neutral $(\mathrm{N})-3$; Agree $(A)=4$; and Strongly Agree $(\mathrm{SA})=5$ is used. The Section on Orphaned Learners' Educational Achievements (OLEA) contained five positively worded statements and five negatively worded statements to determine the extent to which the orphaned learners agreed with the statements on orphaned learners' educational achievements. The orphaned learners' educational achievements statements were: OLEA1-The orphaned learners attend school regularly/ OLEA2- The orphaned learners do not attend school regularly; OLEA3The orphaned learners participate in cocurriculum activities/ OLEA4-The orphaned learners do not participate in co-curriculum activities; OLEA5-The orphaned learners behave well in school/ OLEA6- The orphaned learners do not behave well in school; OLEA7-The orphaned learners pass school examinations and get promoted to the next class/ OLEA8- The orphaned learners do not pass school examinations and get 
promoted to the next class; OLEA9- The orphaned learners always do their home work OLEA10The orphaned learners do not always do their home work. Each of the statements had a 5 Likert scale ranging from Strongly Disagree $(\mathrm{SD})=1$; Disagree $(D)=2$; Neutral $(N)-3$; Agree $(A)=4$; and Strongly Agree $(\mathrm{SA})=5$ is used.

The research instrument was piloted at an orphan support project in the neighbouring Kisumu among 36 orphaned learners. As recommended by Kothari (1985), a pre-test sample of a tenth of the total sample with homogenous characteristic was appropriate for a pilot study. Since the total number of targeted orphaned learners was 363, 36 orphaned learners were equivalent to $10 \%$ of the total sample of orphaned learners. Content validity of the research instruments was ensured through the use of appropriate measures and indicators for each of the variables in the study. The research instruments also used age and class appropriate grammar for all the primary school learners. The statements in the questionnaire were clear and precise. The research instruments were reviewed by the supervisors who are experts in questionnaire design, who made recommendations on what was to be included and removed to ensure that the instruments were not ambiguous and difficult for all the respondents.

Quantitative data was analysed using the Statistical Package for Social Sciences (SPSS Version 21). The questionnaire items were checked for completeness and a follow up undertaken to ensure that lost and unanswered questionnaires were re-administered to ensure increased questionnaire response rate. Each and every questionnaire was given unique identifier codes to ensure confidentiality and anonymity of the respondents. Both descriptive and inferential statistics were analysed. Descriptive statistics such as means, standard deviations, frequencies and percentages counts were presented using frequency and percentage tables. Pearson Correlation Coefficients was computed to determine the association between the design orientation and educational achievement variables. Pearson Correlation Coefficient (r) was applied to reflect degree of linear relationship between appreciative project design orientation and learners' achievements. The null hypotheses were tested at $\alpha=0.05$ level of significance.

A number of ethical issues were considered in this study. These included informed assent and consent, confidentiality, right to privacy, respect for the participants' autonomy, honesty, and participants' right to discontinue. The learners were informed about the purpose and objectives of the study and asked to participate in the study. Only those learners who accepted to participate were involved in the study. Assent of learners was received from their care givers' and or parents' consent for their children to participate in the study. No payments or any form of material or psychological inducements be use to entice the participants into the study. However, refreshments and fare back home were provided to the learners after participating in the study.

\section{Results}

\section{Orphaned Learners' Demographic Profile}

The demographic questionnaire for orphaned learners sought information on the age bracket of the orphaned learners, their gender, orphanhood status, number of siblings, who the orphaned learners live with and the classes they are enrolled in.

Table 1: Orphaned Learners' Demographic Profile

\begin{tabular}{|l|l|l|l|}
\hline Orphaned Learners' Profile & Frequency & Percent (\%) & Cumulative \% \\
\hline Age bracket & \multicolumn{2}{l|}{} \\
\hline \multicolumn{4}{|l|}{} \\
\hline 10-12yrs & 158 & 43.5 & 43.5 \\
\hline 13-15yrs & 175 & 48.2 & 91.7 \\
\hline $16-17 y r s$ & 30 & 8.3 & 100 \\
\hline 18 and above & 0 & 0.0 & 100 \\
\hline Total & 363 & 100.0 & \\
\hline Gender & & & 34.71 \\
\hline Male & 126 & 34.71 & \\
\hline
\end{tabular}




\begin{tabular}{|c|c|c|c|}
\hline Female & 237 & 65.29 & 100 \\
\hline Total & 363 & 100 & \\
\hline \multicolumn{4}{|l|}{ Orphanhood status } \\
\hline Mother dead & 79 & 21.76 & 21.76 \\
\hline Father Dead & 161 & 44.35 & 66.11 \\
\hline Both parents dead & 123 & 33.89 & 100 \\
\hline Total & 363 & 100 & \\
\hline \multicolumn{4}{|l|}{ Number of siblings } \\
\hline $1-2$ & 122 & 33.6 & 33.6 \\
\hline 3-5 & 142 & 39.1 & 72.7 \\
\hline More than 5 & 82 & 22.6 & 95.3 \\
\hline None & 17 & 4.7 & 100 \\
\hline Total & 363 & 100 & \\
\hline \multicolumn{4}{|c|}{ Who do you live with } \\
\hline Mother & 123 & 33.88 & 33.88 \\
\hline Father & 37 & 10.19 & 44.07 \\
\hline Relatives & 161 & 44.35 & 88.40 \\
\hline None & 42 & 11.58 & 100 \\
\hline Total & 363 & 100 & \\
\hline \multicolumn{4}{|l|}{ Class enrolled in } \\
\hline Class 4 & 65 & 17.91 & 17.91 \\
\hline Class 5 & 69 & 19.01 & 36.92 \\
\hline Class 6 & 53 & 14.60 & 51.52 \\
\hline Class 7 & 92 & 25.34 & 76.86 \\
\hline Class 8 & 80 & 22.04 & 98.90 \\
\hline Missing & 4 & 1.10 & 100 \\
\hline Total & 363 & 100 & \\
\hline
\end{tabular}

Table 1 shows that out of the 363 orphaned learners who participated in the study, 175 $(48.2 \%)$ of the sampled orphaned learners, were in the age bracket of 13-15 years. Out of the 363 orphaned learners, $158(43.5 \%)$, were in aged between 10-12 years. The remaining 30 orphaned learners, who constituted $8.3 \%$, were in aged between 16-17 years. This finding suggests that learners were orphaned at early age. Majority of the orphaned learners were female 237(65.29\%) with male orphaned learners the total number of male orphaned learners being $126(34.71 \%)$.

Majority 161 (44.35\%) of the orphaned learners had lost their fathers (paternal orphans), with 123 (33.89\% of the orphaned learners having lost both parents (double orphans), while $79(21.76 \%)$ of the orphaned learners had lost their mothers (maternal orphans). The data suggest that more fathers compared to mothers had died at the time of the study, pointing to the heavy burden for care giving being placed on the mothers and relatives. $142(39.1 \%)$ had between 3-5 siblings; 122 (33.6\%) had between 1-2 siblings; $82(22.6 \%)$ had more than 5 brothers and sisters, while $7(4.7 \%)$ of the orphaned learners did not have brothers or sisters. 161(44.35\%) lived with their relatives, $123(33.88 \%)$ of the orphaned learners lived with their mothers, whereas the remaining of the orphaned learners $42(11.58 \%)$ lived alone (childheaded household); 37 (10.19\%) lived with their fathers. Majority of the orphaned learners $92(25.34 \%)$ were in class $7 ; 80(22.04 \%)$ were in class 8 (candidates); $69(19.01 \%)$ were in class 5; $65(17.91 \%)$ were in class 4 while $4(.10 \%)$ did not indicate their classes. 
Table 2: Descriptive Statistics on Orphaned Learners' Perspectives on Their Educational Achievements

\begin{tabular}{|c|c|c|c|c|c|c|c|c|}
\hline & $\begin{array}{l}\text { Orphaned Learners' } \\
\text { Educational Achievement } \\
\text { Statements }\end{array}$ & & & & & & & \\
\hline Items & Statements & SD(1) & $D(2)$ & $N(3)$ & $A(4)$ & SA(5) & $\begin{array}{l}\text { Mea } \\
n\end{array}$ & SD \\
\hline OLEA1 & $\begin{array}{l}\text { The orphaned learners attend } \\
\text { school regularly }\end{array}$ & $\begin{array}{l}28(7.71 \\
)\end{array}$ & $25(6.9)$ & $\begin{array}{l}24(6 . \\
61)\end{array}$ & $\begin{array}{l}73(20 \\
.11)\end{array}$ & $\begin{array}{l}213(58 \\
.68)\end{array}$ & 4.18 & 1.24 \\
\hline OLEA2 & $\begin{array}{l}\text { The orphaned learners do not } \\
\text { attend school regularly }\end{array}$ & $\begin{array}{l}167(46 . \\
01)\end{array}$ & $61(16.8)$ & $\begin{array}{l}38(10 \\
.47) \\
\end{array}$ & $\begin{array}{l}48(13 \\
.22)\end{array}$ & $\begin{array}{l}49(13 . \\
50)\end{array}$ & 2.34 & 1.49 \\
\hline OLEA3 & $\begin{array}{l}\text { The orphaned learners } \\
\text { participate in co-curriculum } \\
\text { activities }\end{array}$ & $\begin{array}{l}40(11.0 \\
2)\end{array}$ & $\begin{array}{l}49(13.50 \\
)\end{array}$ & $\begin{array}{l}51(14 \\
.0)\end{array}$ & $\begin{array}{l}83(22 \\
.87)\end{array}$ & $\begin{array}{l}140(38 \\
.57)\end{array}$ & 3.68 & 1.37 \\
\hline OLEA4 & $\begin{array}{l}\text { The orphaned learners do not } \\
\text { participate in co-curriculum } \\
\text { activities }\end{array}$ & $\begin{array}{l}111(30 . \\
58)\end{array}$ & $93(25.62$ & $\begin{array}{l}50(13 \\
.77)\end{array}$ & $\begin{array}{l}61(16 \\
.8)\end{array}$ & $\begin{array}{l}48(13 . \\
22)\end{array}$ & 2.58 & 1.43 \\
\hline OLEA5 & $\begin{array}{l}\text { The orphaned learners } \\
\text { behave well in school }\end{array}$ & $\begin{array}{l}38(10.4 \\
7)\end{array}$ & $24(6.61)$ & $\begin{array}{l}34(9 . \\
4)\end{array}$ & $\begin{array}{l}66(18 \\
.2)\end{array}$ & $\begin{array}{l}201(55 \\
.37)\end{array}$ & 4.06 & 1.32 \\
\hline OLEA6 & $\begin{array}{l}\text { The orphaned learners do not } \\
\text { behave well in school }\end{array}$ & $\begin{array}{l}148(40 . \\
87)\end{array}$ & $67(18.5)$ & $\begin{array}{l}60(16 \\
.5)\end{array}$ & $\begin{array}{l}56(15 \\
.4)\end{array}$ & $32(8.8)$ & 2.26 & 1.36 \\
\hline OLEA7 & $\begin{array}{l}\text { The orphaned learners pass } \\
\text { school examinations and get } \\
\text { promoted to the next class }\end{array}$ & $34(9.4)$ & $32(8.8)$ & $\begin{array}{l}28(7 . \\
7)\end{array}$ & $\begin{array}{l}63(17 \\
.4)\end{array}$ & $\begin{array}{l}206(56 \\
.7)\end{array}$ & 4.06 & 1.35 \\
\hline OLEA8 & $\begin{array}{l}\text { Orphaned learners do not } \\
\text { pass school exams and they } \\
\text { have to repeat classes }\end{array}$ & $\begin{array}{l}146(40 . \\
2)\end{array}$ & $65(17.9)$ & $\begin{array}{l}61(16 \\
.8)\end{array}$ & $\begin{array}{l}56(15 \\
.4)\end{array}$ & $35(9.6)$ & 2.35 & 1.40 \\
\hline OLEA9 & $\begin{array}{l}\text { The orphaned learners always } \\
\text { do their home work }\end{array}$ & $25(6.9)$ & $30(8.3)$ & $\begin{array}{l}30(8 . \\
3)\end{array}$ & $\begin{array}{l}73(20 \\
.1)\end{array}$ & $\begin{array}{l}205(56 \\
.5)\end{array}$ & 4.11 & 1.26 \\
\hline OLEA10 & $\begin{array}{l}\text { The orphaned learners do not } \\
\text { always do their home work }\end{array}$ & $\begin{array}{l}188(51 . \\
8)\end{array}$ & $78(21.5)$ & $\begin{array}{l}42(11 \\
.6)\end{array}$ & $\begin{array}{l}25(6 . \\
9)\end{array}$ & $30(8.3)$ & 1.98 & 1.30 \\
\hline
\end{tabular}

Table 2 presents the descriptive statistics on the orphaned learners' perspectives on their Educational Achievements (OLEA). Item OLEA1 sought to establish the extent to which orphaned learners attend school regularly. Out of 363 orphaned learners, $28(7.71 \%)$ strongly disagreed that orphaned learners attend school regularly, $25(6.9 \%)$ disagreed with the statement, 24(6.61\%) of the orphaned learners were neutral, 73(20.11) agreed with the statement, while $213(58.68 \%$ ) of the orphaned learners strongly agreed that orphaned learners attend school regularly. The mean score for the orphaned learners' response on item OLEA 1 was 4.18 while the standard deviation was 1.24 , indicating that according to the orphaned learners, orphaned learners attend school regularly. Item OLEA2 sought to establish the extent to which orphaned learners did not attend school regularly. Out of 363 orphaned learners, 167(46.01\%) strongly disagreed that orphaned learners do not attend school regularly, $61(16.8 \%)$ disagreed with the statement, $38(10.47 \%)$ of the orphaned learners were neutral, 48(13.22) agreed with the statement, while $49(13.5 \%)$ of the orphaned learners strongly agreed that orphaned learners do not attend school regularly. The mean score for the orphaned learners' response on item OLEA 2 was 2.34 while the standard deviation was 1.49 , indicating that orphaned learners disagreed with the statement that orphaned learners do not attend school regularly.

Item OLEA 3 sought to establish the extent to which orphaned learners participate in cocurricular activities. Out of the 363 orphaned learners who responded to this item, 40(11.02\%) 
strongly disagreed with the statement that orphaned learners participate in co-curricular activities, 49(13.50\%) disagreed with the statement, 51(14.0\%) were neutral, 83(22.87\%) agreed with the statement and 140(38.57\%) strongly agreed with the statement that orphaned learners participate in co-curricular activities. The mean score and the standard deviation for the orphaned learners on this item was 3.68 and 1.37, respectively, suggesting that majority of the orphaned learners agreed that orphaned learners participate in co-curricular activities. Item OLEA 4 sought to establish the extent to which the orphaned learners do not participate in cocurriculum activities. Out of the 363 orphaned learners who responded to this item, 111(30.58\%) strongly disagreed with the statement that orphaned learners do not participate in cocurricular activities, 93(25.62\%) disagreed with the statement, $50(13.77 \%)$ were neutral, $61(16.8 \%)$ agreed with the statement and $48(13.22 \%)$ strongly agreed with the statement that orphaned learners do not participate in cocurricular activities. The mean score and the standard deviation for the orphaned learners on this item was 2.58and 1.43, respectively, suggesting that majority of the orphaned learners disagreed with the statement that orphaned learners do not participate in co-curricular activities.

Item OLEA 5 sought to establish the extent to which orphaned learners are disciplined. Out of the 363 orphaned learners who responded to this item, 111(30.58\%) strongly disagreed with the statement that orphaned learners are disciplined, 93(25.62\%) disagreed with the statement, $50(13.77 \%)$ were neutral, 61(16.8\%) agreed with the statement and 48(13.22\%) strongly agreed with the statement that orphaned learners are disciplined. The mean score and the standard deviation for the orphaned learners on this item was 2.58 and 1.43 , respectively, suggesting that majority of the orphaned learners agreed with the statement that orphaned learners are disciplined. Item OLEA 6 sought to establish the extent to which orphaned learners are not disciplined. Out of the 363 orphaned learners who responded to this item, 148(40.87) strongly disagreed with the statement that orphaned learners are not disciplined, 67(18.5) disagreed with the statement, 60(16.5) were neutral, 56(15.4) agreed with the statement and 32(8.8) strongly agreed with the statement that orphaned learners are not disciplined. The mean score and the standard deviation for the orphaned learners on this item was 2.26 and 1.36, respectively, suggesting that majority of the orphaned learners disagreed with the statement that orphaned learners are not disciplined.

Item OLEA7 sought to establish the extent to which orphaned learners pass school based examinations and progress to the next grade. Out of the 363 orphaned learners who responded to this item, 34(9.4\%) strongly disagreed with the statement that orphaned learners pass school based examinations and progress to the next grade, 32 $(8.8 \%)$ disagreed with the statement, $28(7.7 \%)$ were neutral, 63(17.4\%) agreed with the statement and 206(56.7\%) strongly agreed with the statement that orphaned learners pass school based examinations and progress to the next grade. The mean score and the standard deviation for the orphaned learners on this item was 4.06 and 1.35 , respectively, suggesting that majority of the orphaned learners agreed with the statement that orphaned learners pass school based examinations and progress to the next grade. Item OLEA8 sought to establish the extent to which orphaned learners do not pass school based examinations and do not progress to the next grade. Out of the 363 orphaned learners who responded to this item, $146(40.2 \%)$ strongly disagreed with the statement that orphaned learners do not pass school based examinations and do not progress to the next grade, 65(17.9\%) disagreed with the statement, $61(16.8 \%)$ were neutral, 56(15.4\%) agreed with the statement and 35(9.6\%) strongly agreed with the statement that orphaned learners do not pass school based examinations and do not progress to the next grade The mean score and the standard deviation for the orphaned learners on this item was 2.35 and 1.40 , respectively, suggesting that majority of the orphaned learners disagreed with the statement that orphaned learners do not pass school based examinations and do not progress to the next grade.

Item OLEA9 sought to establish the extent to which orphaned learners always do their home work. Out of the 363 orphaned learners who responded to this item, 25(6.9\%) strongly disagreed with the statement that orphaned learners always do their home work, 30(8.3\%) disagreed with the statement, 30(8.3\%) were neutral, 73(20.1\%) agreed with the statement and $205(56.5 \%)$ strongly agreed with the statement that orphaned learners always do their home work. 
The mean score and the standard deviation for the orphaned learners on this item was 4.11and 1.26, respectively, suggesting that majority of the orphaned learners agreed with the statement that orphaned learners always do their home work. Item OLEA10 sought to establish the extent to which orphaned learners do not always do their home work. Out of the 363 orphaned learners who responded to this item, 188(51.8\%) strongly disagreed with the statement that orphaned learners do not always do their home work,
$78(21.5 \%)$ disagreed with the statement, $42(11.6 \%)$ were neutral, $25(6.9 \%)$ agreed with the statement and $30(8.3 \%)$ strongly agreed with the statement that orphaned learners do not always do their home work. The mean score and the standard deviation for the orphaned learners on this item was 1.98 and 1.30 , respectively, suggesting that majority of the orphaned learners disagreed with the statement that orphaned learners do not always do their home work.

Table 3: Descriptive Statistics on Orphaned Learners' Perspectives on Appreciative Project Design Orientation

\begin{tabular}{|c|c|c|c|c|c|c|c|c|}
\hline & $\begin{array}{l}\text { Statements on } \\
\text { Appreciative }\end{array}$ & $S D(1)$ & $D(2)$ & $N(3)$ & $A(4)$ & SA(5) & Mean & SD \\
\hline & $\begin{array}{l}\text { Design } \\
\text { Orientation } \\
\text { (ADO) }\end{array}$ & $f(\%)$ & $f(\%)$ & $f(\%)$ & $f(\%)$ & $f(\%)$ & & \\
\hline AD01 & $\begin{array}{l}\text { The orphaned } \\
\text { learners are } \\
\text { motivated by the } \\
\text { project }\end{array}$ & $23(6.6 \%)$ & $15(4.1 \%)$ & $\begin{array}{l}26(7.2 \% \\
)\end{array}$ & $80(22 \%)$ & $\begin{array}{l}219(61 \\
\%)\end{array}$ & 4.26 & $\begin{array}{l}1.16 \\
7\end{array}$ \\
\hline ADO2 & $\begin{array}{l}\text { The orphaned } \\
\text { learners are not } \\
\text { motivated by the } \\
\text { project }\end{array}$ & $\begin{array}{l}\text { 124(34.6 } \\
\%)\end{array}$ & $61(17 \%)$ & $\begin{array}{l}\text { 63(17.6 } \\
\%)\end{array}$ & $\begin{array}{l}\text { 63(17.6 } \\
\%)\end{array}$ & $\begin{array}{l}\text { 52(14.3 } \\
\%)\end{array}$ & 2.58 & 1.44 \\
\hline ADO3 & $\begin{array}{l}\text { The orphaned } \\
\text { learners are } \\
\text { appreciated by } \\
\text { the project }\end{array}$ & $29(8.1 \%)$ & $31(8.7 \%)$ & $\begin{array}{l}\text { 39(10.9 } \\
\%)\end{array}$ & $\begin{array}{l}95(26.2 \\
\%)\end{array}$ & $\begin{array}{l}169(47 . \\
2 \%)\end{array}$ & 3.95 & 1.29 \\
\hline AD04 & $\begin{array}{l}\text { The orphaned } \\
\text { learners are not } \\
\text { appreciated by } \\
\text { the project }\end{array}$ & $106(30 \%)$ & $69(19.5 \%)$ & $\begin{array}{l}66(18.7 \\
\%)\end{array}$ & $\begin{array}{l}66(18.7 \\
\%)\end{array}$ & $\begin{array}{l}86(18.9 \\
\%)\end{array}$ & 2.68 & 1.45 \\
\hline ADO5 & $\begin{array}{l}\text { The orphaned } \\
\text { learners are } \\
\text { encouraged by } \\
\text { the project }\end{array}$ & $29(8.2 \%)$ & $26(7.3 \%)$ & $\begin{array}{l}45(12.4 \\
\%)\end{array}$ & $\begin{array}{l}88(24.8 \\
\%)\end{array}$ & $\begin{array}{l}175(49 . \\
3 \%)\end{array}$ & 4.00 & 1.28 \\
\hline AD06 & $\begin{array}{l}\text { The orphaned } \\
\text { learners are not } \\
\text { encouraged by } \\
\text { the project }\end{array}$ & $\begin{array}{l}117(33.5 \\
\%)\end{array}$ & $75(21.5 \%)$ & $\begin{array}{l}\text { 57(16.3 } \\
\%)\end{array}$ & $\begin{array}{l}\text { 54(15.5 } \\
\%)\end{array}$ & $\begin{array}{l}\text { 60(17.1 } \\
\%)\end{array}$ & 2.53 & 1.42 \\
\hline ADO7 & $\begin{array}{l}\text { The orphaned } \\
\text { learners are } \\
\text { praised by the } \\
\text { project }\end{array}$ & $\begin{array}{l}49(13.8 \% \\
)\end{array}$ & $36(10.2 \%)$ & $\begin{array}{l}59(16.7 \\
\%)\end{array}$ & $\begin{array}{l}89(25.1 \\
\%)\end{array}$ & $\begin{array}{l}130(36 . \\
7 \%)\end{array}$ & 3.66 & 1.36 \\
\hline AD08 & $\begin{array}{l}\text { The orphaned } \\
\text { learners are not } \\
\text { praised by the } \\
\text { project }\end{array}$ & $\begin{array}{l}89(25.4 \% \\
)\end{array}$ & $79(22.6 \%)$ & $\begin{array}{l}\text { 70(19.9 } \\
\%)\end{array}$ & $\begin{array}{l}\text { 60(17.1 } \\
\%)\end{array}$ & $\begin{array}{l}\text { 65(18.6 } \\
\%)\end{array}$ & 2.81 & 1.46 \\
\hline
\end{tabular}




\begin{tabular}{|l|l|l|l|l|l|l|l|l|}
\hline AD09 & $\begin{array}{l}\text { The orphaned } \\
\text { learners are } \\
\text { valued by the } \\
\text { project }\end{array}$ & $\begin{array}{l}37(10.5 \% \\
\text { ) }\end{array}$ & $29(8.3 \%)$ & $\begin{array}{l}52(14.3 \\
\%)\end{array}$ & $\begin{array}{l}89(25.4 \\
\%)\end{array}$ & $\begin{array}{l}156(44 . \\
4 \%)\end{array}$ & 3.85 & 1.35 \\
\hline AD010 & $\begin{array}{l}\text { The orphaned } \\
\text { learners are not } \\
\text { valued by the } \\
\text { project }\end{array}$ & $\begin{array}{l}111(32.7 \\
\%)\end{array}$ & $78(23 \%)$ & $\begin{array}{l}68(20.1 \\
\%)\end{array}$ & $\begin{array}{l}64(18.4 \\
\%)\end{array}$ & $\begin{array}{l}42(12.4 \\
\%)\end{array}$ & 2.48 & 1.38 \\
\hline
\end{tabular}

Table 3 presents the descriptive statistics on orphaned learners' perspectives on Appreciative Project Design Orientation (ADO). Five positively worded statements and five negatively worded statements were used to determine the perspectives of the orphaned learners on the influence of appreciative design orientation on their educational achievements. ADO1 was positively worded and sought to establish the extent to which orphaned learners agreed, disagreed or were neutral on the statement that orphaned learners are motivated by the project. $23(6.6 \%)$ of the orphaned learners strongly disagreed with the statement; $15(4.1 \%)$ of the orphaned learners disagreed with the statement; $26(7.2 \%)$ were neutral; 80(22\%) agreed with the statement, while $219(61 \%)$ strongly agreed with the statement that orphaned learners are motivated by the project. The mean of ADO1 item was 4.26, with a standard deviation of 1.167, suggesting that orphaned learners were motivated by the projects. ADO2 was negatively worded and sought to establish the extent to which orphaned learners agreed, disagreed or were neutral on the statement that orphaned learners are not motivated by the project. $124(34.6 \%)$ of the orphaned learners strongly disagreed with the statement; 61(17\%) disagreed with the statement, 63(17.6\%) were neutral, 63(17.6\%) agreed with the statement, $52(14.3 \%)$ agreed with the statement, while $52(14.3 \%)$ strongly agreed with the statement. The mean of the statement was 2.58 with s standard deviation of 1.44 suggesting that the orphaned learners disagreed with the statement that they are not motivated by the projects.

ADO3 was positively worded and sought to establish the extent to which orphaned learners agreed, disagreed or were neutral on the statement that orphaned learners are appreciated by the project. $29(8.1 \%)$ of the orphaned learners strongly disagreed with the statement; $31(8.7 \%)$ disagreed with the statement, 39(10.9\%) were neutral, 95(26.2\%) agreed with the statement, while $169(47.2 \%)$ strongly agreed with the statement. The mean of the statement was 3.95 with s standard deviation of 1.29 suggesting that the orphaned learners agreed with the statement that they are appreciated by the project. ADO4 was negatively worded and sought to establish the extent to which orphaned learners agreed, disagreed or were neutral on the statement that orphaned learners are not appreciated by the project. $106(30 \%)$ of the orphaned learners strongly disagreed with the statement; 69(19.5\%) disagreed with the statement, 66(18.7\%) were neutral, 66(18.7\%) agreed with the statement, while $86(18.9 \%)$ strongly agreed with the statement. The mean of the statement was 2.68 with s standard deviation of 1.45 suggesting that the orphaned learners disagreed with the statement that they are not appreciated by the projects.

ADO5 was positively worded and sought to establish the extent to which orphaned learners agreed, disagreed or were neutral on the statement that orphaned learners are encouraged by the project. $29(8.2 \%)$ of the orphaned learners strongly disagreed with the statement; $26(7.3 \%)$ disagreed with the statement, $45(12.4 \%)$ were neutral, $88(24.8 \%)$ agreed with the statement, while $175(18.9 \%)$ strongly agreed with the statement. The mean of the statement was 4.00 with $\mathrm{s}$ standard deviation of 1.28 suggesting that the orphaned learners agreed with the statement that they are encouraged by the projects. ADO6 was negatively worded and sought to establish the extent to which orphaned learners agreed, disagreed or were neutral on the statement that orphaned learners are not encouraged by the project. $117(33.5 \%)$ of the orphaned learners strongly disagreed with the statement; $75(21.5 \%)$ disagreed with the statement, $57(16.3 \%)$ were neutral, 54(15.5\%) agreed with the statement, while $60(17.1 \%)$ strongly agreed with the statement. The mean of the statement was 2.53 with a standard deviation of 1.45 suggesting that the orphaned learners disagreed with the statement that they are not encouraged by the projects. 
ADO7 was positively worded and sought to establish the extent to which orphaned learners agreed, disagreed or were neutral on the statement that orphaned learners are praised by the project. $49(13.8 \%)$ of the orphaned learners strongly disagreed with the statement; $36(10.2 \%)$ disagreed with the statement, 59(16.7\%) were neutral, $89(25.1 \%)$ agreed with the statement, while $130(36.7 \%)$ strongly agreed with the statement. The mean of the statement was 3.66 with a standard deviation of 1.36 suggesting that the orphaned learners agreed with the statement that they are praised by the projects. ADO8 was negatively worded and sought to establish the extent to which orphaned learners agreed, disagreed or were neutral on the statement that orphaned learners are not praised by the project. $89(25.4 \%)$ of the orphaned learners strongly disagreed with the statement; 79(22.6\%) disagreed with the statement, 70(19.9\%) were neutral, $60(17.3 \%)$ agreed with the statement, while $65(18.1 \%)$ strongly agreed with the statement. The mean of the statement was 2.81 with a standard deviation of 1.46 suggesting that the orphaned learners disagreed with the statement that they are not praised by the projects.

ADO9 was positively worded and sought to establish the extent to which orphaned learners agreed, disagreed or were neutral on the statement that orphaned learners are valued by the project. $37(10.5 \%)$ of the orphaned learners strongly disagreed with the statement; $29(8.3 \%)$ disagreed with the statement, 53(14.3\%) were neutral,
$89(25.4 \%)$ agreed with the statement, while $156(36.7 \%)$ strongly agreed with the statement. The mean of the statement was 3.85 with a standard deviation of 1.35 suggesting that the orphaned learners agreed with the statement that they are valued by the projects. ADO10 was negatively worded and sought to establish the extent to which orphaned learners agreed, disagreed or were neutral on the statement that orphaned learners are not valued by the project. $111(32.7 \%)$ of the orphaned learners strongly disagreed with the statement; 78(23\%) disagreed with the statement, 68(20.1\%) were neutral, $64(18.4 \%)$ agreed with the statement, while $42(18.1 \%)$ strongly agreed with the statement. The mean of the statement was 2.48 with a standard deviation of 1.38 suggesting that the orphaned learners disagreed with the statement that they are not valued by the projects.

a) Correlation Analysis on Appreciative Project Design Orientation and Orphaned Learners' Educational Achievements

Pearson product moment correlation coefficient was used in order to establish the existence or non existence of significance relationship as well as the degree or strength of association between Appreciative Design Orientation and Orphaned Learners' Educational Achievements, from the perspectives of the orphaned learners themselves. The bivariate correlation through Pearson correlation coefficient was opted for since the data scale was interval in nature.

Table4: Correlation Statistics on Orphaned Learners' Perspectives on Appreciative Project Design Orientation and Orphaned Learners' Educational Achievements

\begin{tabular}{|c|c|c|}
\hline \multicolumn{2}{|c|}{$\begin{array}{l}\text { Correlations of individual statements on } \\
\text { Appreciative Design Orientation }\end{array}$} & $\begin{array}{c}\text { Orphaned Learners } \\
\text { Educational Achievements(P- } \\
\text { Values) } \\
.168^{* *}\end{array}$ \\
\hline $\begin{array}{l}\text { ADO1:The orphaned } \\
\text { learners are motivated by } \\
\text { the project } \\
\text { ADO2:The orphaned } \\
\text { learners are not motivated } \\
\text { by the project } \\
\text { ADO3:The orphaned } \\
\text { learners are appreciated by } \\
\text { the project } \\
\text { ADO4: The orphaned } \\
\text { learners are not appreciated } \\
\text { by the project } \\
\text { ADO5:The orphaned }\end{array}$ & $\begin{array}{l}\text { Pearson Correlation } \\
\text { Sig. (2-tailed) } \\
\text { N } \\
\text { Pearson Correlation } \\
\text { Sig. (2-tailed) } \\
\text { N } \\
\text { Pearson Correlation } \\
\text { Sig. (2-tailed) } \\
\text { N } \\
\text { Pearson Correlation } \\
\text { Sig. (2-tailed) } \\
\text { N } \\
\text { Pearson Correlation }\end{array}$ & $\begin{array}{r}.168^{* * *} \\
.001 \\
363 \\
-.116^{*} \\
.029 \\
363 \\
.028^{* *} \\
.000 \\
363 \\
-.118^{*} \\
.027 \\
363 \\
.275^{* *}\end{array}$ \\
\hline
\end{tabular}




\begin{tabular}{|ll|r|} 
learners are encouraged by & Sig. (2-tailed) & .000 \\
the project & $\mathrm{N}$ & 363 \\
ADO6:The orphaned & Pearson Correlation & $-.139^{* *}$ \\
learners are not encouraged & Sig. (2-tailed) & .010 \\
by the project & $\mathrm{N}$ & 363 \\
ADO7:The orphaned & Pearson Correlation & $.156^{* *}$ \\
learners are praised by the & Sig. (2-tailed) & .003 \\
project & $\mathrm{N}$ & 363 \\
ADO8: The orphaned & Pearson Correlation \\
learners are not praised by & Sig. (2-tailed) & $-.203^{* *}$ \\
the project & $\mathrm{N}$ & .000 \\
ADO9:The orphaned & Pearson Correlation & 363 \\
learners are valued by the & Sig. (2-tailed) & $.226^{* *}$ \\
project & $\mathrm{N}$ & .000 \\
ADO10:The orphaned & Pearson Correlation & 363 \\
learners are not valued by & Sig. (2-tailed) & $-.268^{* *}$ \\
the project & $\mathrm{N}$ & .000 \\
& Pearson Correlation & 363 \\
Orphaned Learners & Sig. (2-tailed) & 1 \\
Educational Achievements & $\mathrm{N}$ & \\
\hline
\end{tabular}

The correlation output table 4 shows that all the Appreciative Design Orientation characteristics were significantly related $(\mathrm{P}$-values $<0.05)$ against the indicators of Orphaned Learners' Educational Achievements. Similarly, the positively worded Appreciative Design Orientation characteristics were all positively correlated with Orphaned Learners' Educational Achievements, while the negatively worded Appreciative Design Orientation characteristics exhibited negative correlation with Orphaned Learners' Educational Achievements. The small p-values $(p<0.05)$ implies that there is a significant relationship between Appreciative Design Orientation and Orphaned Learners' Educational Achievements, leading to rejection of the null hypothesis that Appreciative design orientation does not significantly influence orphaned learners' educational achievements in Homa Bay County. From the perspectives of the orphaned learners, it can safely be indicated that there is a significant relationship between Appreciative Design Orientation characteristics and Orphaned Learners' Educational Achievements.

Regression Analysis on Appreciative Design Orientation and Orphaned Learners' Educational Achievements

Simple linear regression was adopted to investigate how the Appreciative Design Orientation individually predicted Orphaned Learners' Educational Achievement, from the perspectives of the orphaned learners themselves. The underpinning rationale for using the model was to establish how each predictor significantly or insignificantly predicted Orphaned Learners' Educational Achievements; secondly, the purpose of using this model was to find out which of the Designs Orientation best predicted Orphaned Learners' Educational Achievements and finally to confirm whether the model was a best fit for predicting Orphaned Learners' Educational Achievements.

Table 5: Model Summary Table on Appreciative Project Design Orientation and Orphaned Learners' Educational Achievements

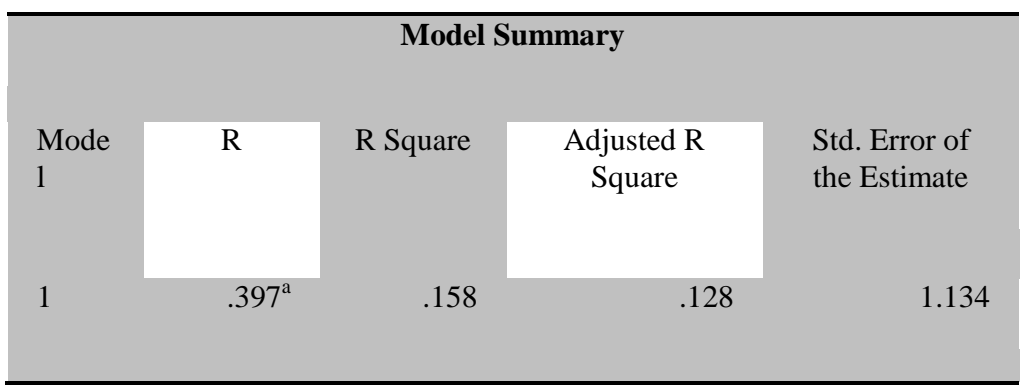


Table 5 presents the regression model summary on orphaned learners' perspectives on influence of Appreciative Design Orientation on Orphaned Learners' Educational Achievements. The model summary table, indicates that there is a positive multiple correlation coefficient $(\mathrm{R}=0.397)$ between Orphaned Learners' Educational Achievements and Appreciative Design Orientation; and those predicted by the regression model. In addition, the coefficient of determination $\left(\mathrm{R}^{2}=15.8\right)$ suggests that the amount of variance in Orphaned Learners' Educational Achievements is explained by the Appreciative Design Orientation.

Table 6: An ANOVA on the Regression on Appreciative Project Design Orientation and Orphaned Learners' Educational Achievements

\begin{tabular}{|c|c|c|c|c|c|c|}
\hline \multicolumn{7}{|c|}{ ANOVA $^{a}$} \\
\hline \multicolumn{2}{|c|}{ Model } & $\begin{array}{l}\text { Sum of } \\
\text { Squares }\end{array}$ & df & $\begin{array}{l}\text { Mean } \\
\text { Square }\end{array}$ & $F$ & Sig. \\
\hline \multirow[t]{3}{*}{1} & $\begin{array}{l}\text { Regressi } \\
\text { on }\end{array}$ & 67.707 & 10 & 6.771 & 5.265 & $.000^{b}$ \\
\hline & Residual & 361.372 & 353 & 1.286 & & \\
\hline & Total & 429.079 & 363 & & & \\
\hline
\end{tabular}

a. Dependent Variable: Orphaned Learners educational Achievements

b. Predictors: (Constant), Appreciative Design Orientations

Table 6 presents the ANOVA on the regression on significantly influence Orphaned Learners' the perspectives of orphaned learners' on Educational Achievements in Homa Bay County) influence of Appreciative Design Orientation on was rejected, since $(\mathrm{F}(10,353)=5.265$, Orphaned Learners' Educational Achievements. $\mathrm{P}=0.000<0.05$, and so concluded that at least one The above ANOVA table provides F-test for the of the explanatory variables was significantly null hypothesis that none of the explanatory related to the orphaned learners' educational variables from Appreciative Design Orientation achievements. The data suggests that, according to are related to Orphaned Learners' Educational the orphaned learners, Appreciative Design Achievements. Here, the null hypothesis $\left(\mathrm{H}_{0} 1\right.$ : Orientation has a strong positive influence on their Appreciative Design Orientation does not educational achievements.

Table 7: Coefficients for the Regression on Appreciative Project Design Orientation and Orphaned Learners' Educational Achievements

\begin{tabular}{|l|l|r|r|r|r|r|}
\hline \multicolumn{2}{|c|}{} & \multicolumn{2}{|c|}{\begin{tabular}{c} 
Coefficients $^{\text {a }}$ \\
Cnstandardized \\
\multicolumn{2}{|l|}{ Coefficients }
\end{tabular}} & $\begin{array}{c}\text { Standardize } \\
\text { d } \\
\text { Coefficients }\end{array}$ & t & Sig. \\
\cline { 2 - 7 } & \multicolumn{2}{|c|}{ B } & Std. Error & Beta & \\
\hline \multirow{3}{*}{1} & (Constant) & 2.852 & .481 & & 5.929 & .000 \\
\cline { 2 - 7 } & $\begin{array}{l}\text { Appreciative Design } \\
\text { Orientation }\end{array}$ & .164 & .058 & .169 & 2.830 & .005 \\
\hline
\end{tabular}

a. Dependent Variable: Orphaned Learners Educational Achievements

b. Predictors: (Constant), Appreciative Design Orientations Table 7 presents the coefficients for the regression on the perspectives of orphaned learners on the influence of Appreciative Design Orientation on their Educational Achievements. The table above provides estimates of the regression coefficients

predicted by Appreciative Design Orientation; with a P-value of 0.005; Appreciative Design Orientation is significantly related to Orphaned Learners' Educational Achievements. The simple linear regression model is $\mathrm{Y}=2.852+0.164 \mathrm{X}_{1}$, 
implies that were there no Appreciative Design Orientation adopted in the projects, Orphaned learners' educational achievements would be 2.852. According to the orphaned learners, Appreciative Design Orientation had a positive effect on their educational achievements. Thus, the null hypothesis that Appreciative Design Orientation does not significantly influence orphaned learners' educational achievements in Homa Bay County was again rejected.

\section{Discussion}

The purpose of this study was to examine the extent to which project design orientation influence orphaned learners' educational achievements in Homa Bay County, Kenya. The first research objective was to examine the extent to which appreciative design orientation influence orphaned learners' educational achievements in Homa Bay County. The independent variable in this study was appreciative design orientation. Appreciative design orientation was defined as orphan support project design orientation that values the opinions of the orphaned learners. The study attempted to establish the extent to which Appreciative Design Orientation influence Orphaned Learners' Educational Achievements in Homa Bay County.

Appreciative project design orientation, conceptualised as project design approach that appreciates, recognises and positively affirms disadvantaged and vulnerable children (Shier, 2001), is believed to have beneficial influence on a wide range of outcomes, including educational outcomes for disadvantaged and vulnerable children, like the orphaned learners (Shier, 2001; UNICEF, 2008b). From the results of the study, motivation, appreciation, encouragement, praise and valuing of the orphaned learners were found to be important indicators of appreciative design orientation.

The results of the descriptive statistics on the orphaned learners' perspectives on educational achievements indicate that majority of the orphaned learners strongly agreed that school attendance, participation in co-curricular activities, learner discipline, home work completion and grade progression, were important indicators of orphaned learners' educational achievements. The findings of the study are consistent with the findings of other studies that found that school attendance, participation in co-curricular activities; school discipline, home work completion and grade progression are important indicators of learners' educational achievements ( Posso and Feeny, 2016; Saporito, 2017; Cabus and Witte, 2015; Visaria, et al., 2016; Belton, et al., 2017; Stephens, et al., 2016; Imms, Froude, et al., 2016; Hungi, Ngware and Abuya, 2014; Hunter and May, 2011; Klapproth, et al., 2016; Moye, 2015; Salgong, Ngumi and Chege, 2016; Merriman, et al., 2016; Rosário, et al., 2015); Valle, et al.,2015).

The inferential findings indicate that there is a positive multiple correlation coefficient $(\mathrm{R}=0.486)$ between Orphaned Learners' Educational Achievements and Appreciative Design Orientation and those predicted by the regression model. In addition, there is a positive multiple correlation coefficient $(\mathrm{R}=0.397)$ between Orphaned Learners' Educational Achievements and Appreciative Design Orientation; and those predicted by the regression model. In addition, the coefficient of determination $\left(\mathrm{R}^{2}=15.8\right)$ suggests that the amount of variance in Orphaned Learners' Educational Achievements is explained by the Appreciative Design Orientation. From the ANOVA results, the null hypothesis $\left(\mathrm{H}_{0} 1\right.$ : Appreciative Design Orientation does not significantly influence orphaned learners' educational achievements in Homa Bay County) was rejected since $(\mathrm{F}(10,353)=5.265$, $\mathrm{P}=0.000<0.05$, and so concluded that at least one of the explanatory variables was significantly related to the orphaned learners' educational achievements. The data suggests that, according to the orphaned learners, Appreciative Design Orientation has a strong positive influence on their educational achievements. The results of this study are consistent with the findings of studies that have indicated significant relationships between appreciative design orientation and learners' educational achievements (Bergmark and Alerby, 2008; Abildsnes, Stea, Berntsen, Omfjord and Rohde, 2015; Dutcher, et al, .2016; Powers, et al., 2016; Marie, 2016).

\section{Conclusions and Recommendations}

The governments of Kenya, development partners and community based organizations involved in orphan support programming should ensure the integration of appreciative design orientation and approaches when designing and implementing orphan support projects. The study has demonstrated that appreciative design orientations, approaches and mind sets have significant positive 
influence on the educational achievements of orphaned learners. The integration of appreciative project design orientation may call for special training and capacity building not just to project designers but also to policy makers, donors and organizations and individuals involved in orphan support programming.

Whereas the educational achievements of orphaned learners is at the heart of orphan support programming, the absence of a documented policy on orphaned learners' educational achievements has affected the realization of the educational achievement goals in orphan support projects. There is strong research evidence that despite the efforts to promote the education of orphaned learners in the country, the achievement gap is still widening. Compared to non orphaned learners, a number of orphaned learners still have poor educational outcomes. The development and enforcement of educational achievement policy, which is holistic and not just focussed on improving test scores and passing examinable subjects, will hopefully reduce and seal the gap. The government of Kenya should ensure the development of an educational achievement policy to be implemented by all stakeholders involved in orphan support programming.

\section{References}

[1] Abildsnes, E., Stea, T. H., Berntsen, S., Omfjord, C. S., \& Rohde, G. (2015). Physical education Teachers' and public health Nurses' perception of Norwegian high school Students' participation in physical education - a focus group study. BMC Public Health, 15(1), 1-9. doi:10.1186/s12889-015-2660-y

[2] Anderson, A. (2005): The Community Builder's Approach to Theory of Change: A Practical Guide to Theory Development, New York: Aspen Institute Roundtable on Community Change.

[3] Baumgartner, H., \& Steenkamp, J.B.E. (2001). Response styles in marketing research: A cross national investigation. Journal of Marketing Research, 38(2), 143-156.

[4] Belton, S., Prior, P., Wickel, E., \& Woods, C. (2017). The impact of participation in extracurricular physical activity on males from disadvantaged schools. European Physical Education Review, 23(1), 60-72. doi:10.1177/1356336X15625381
[5] Bergmark, U., \& Alerby, E. (2008). Developing an Ethical School through Appreciating Practice? Students' Lived Experience of Ethical Situations in School. Ethics and Education, 3(1), 41-55.

[6] Cabus, S., \& Witte, K. (2015). The effectiveness of active school attendance interventions to tackle dropout in secondary schools: a Dutch pilot case. Empirical Economics, 49(1), 65-80. doi:10.1007/s00181-014-0865-z

[7] Dutcher, J. M., Creswell, J. D., Pacilio, L. E., Harris, P. R., Klein, W. P., Levine, J. M., \& ... Eisenberger, N. I. (2016). Self-Affirmation Activates the Ventral Striatum. Psychological Science (Sage PublicationsInc.),27(4),455466. doi:10.1177/0956797615625989

[8] Ehn, P. (1993). Scandinavian Design: On Participation and Skill. In Schuler, D. and Namioka, A. eds. Erlbaum Associates, New Jersey.

[9] Eunsook, H., Min, W., \& Yun, P. (2011). Discrepancies Between Students' and Primary school teachers' Perceptions of Home Work Completion. Journal of Advanced Academics, 22(2), 280-308.

[10]Evans, D., and Miguel, E. (2007. "Orphaned learners and Schooling in Africa: A Longitudinal Analysis." Demography, Vol.44(1), pp.35-57.

[11]Gorski, P.C. (2010). Unlearning Project Ideology and the Scornful Gaze: Thoughts on Authenticating the Class Discourse in Education. Integrative Studies. George Mason University.

[12]Greenbaum, J. and Kyng, M. eds. (1991). Design at work : cooperative design of computer systems. Lawrence Erlbaum Associates

[13]James, C. (2011): Theory of Change Review. A report commissioned by Comic Relief, Comic Relief.

[14]Klapproth, F., Schaltz, P., Brunner, M., Keller, U., Fischbach, A., Ugen, S., \& Martin, R. (2016). Short-term and medium-term effects of grade retention in secondary school on academic achievement and psychosocial outcome variables. Learning \& Individual Differences, 50182-194. doi:10.1016/j.lindif.2016.08.014

[15]Kothari, C.R (1985). Research Methodology: Methods and Techniques. Vishna Prakashan, New Delhi. 
[16]Krejcie, R.V and Morgan, D. W.(1970). Determining Sample Size for Research Activities. Educational and Psychological Measurement, 30, 607-610.

[17]Marie, J. A. (2016). Student Views on the Value of Feedback. Journal Of Education And Training Studies, 4(6), 207-213.

[18]Moye, G. P. (2015). Students' Indiscipline and Principal Attitude in Ondo State Secondary Schools. Journal of Education and Practice, 6(16), 80-85.

[19]Nunnally, J.C. (1978). Psychometric theory (2nd ed.). New York: McGraw- Hill.

[20]Podsakoff, P.M., MacKenzie, S.B., Lee, J.Y., \& Podsakoff, N.P. (2003). Common method biases in behavioral research: A critical review of the literature and recommended remedies. Journal of Applied Psychology, 88(5), 879903.

[21]Posso, A., \& Feeny, S. (2016). Beyond enrolments: the determinants of primaryschool attendance in Melanesia. Journal of The Asia Pacific Economy, 21(4), 531-548. doi:10.1080/13547860.2016.1153205

[22]Powers, J. T., Cook, J. E., Purdie-Vaughns, V., Garcia, J., Apfel, N., \& Cohen, G. L. (2016). Changing Environments by Changing Individuals: The Emergent Effects of Psychological Intervention. Psychological Science (0956-7976), 27(2), 150-160. doi:10.1177/0956797615614591.

[23]Rosário, P., Núñez, J. C., Vallejo, G., Cunha, J., Nunes, T., Suárez, N., \& ... Moreira, T. (2015). The effects of teachers' Home Work Completion follow-up practices on students' EFL performance: a randomized-group design. Frontiers in Psychology, 61528. doi:10.3389/fpsyg.2015.01528.

[24]Shier, H. (2001). Pathways to Participation openings, opportunities and obligations: a new model for enhancing children's participation in decision-making, in line with Article 12.1 of the United Nations Convention on the rights of the child. Children \&Society, 15(2): 107-117.

[25]Taniguchi, K., \& Hirakawa, Y. (2016). Dynamics of Community Participation, Student Achievement and School Management: The Case of Primary Schools in a Rural Area of Malawi. Compare: A Journal Of Comparative And International Education, 46(3), 479-502.
[26]UNICEF(2008b). The State of the World's Children: Maternal and Newborn Health. New York.

[27]Valencia, R. R. (2010). Dismantling Contemporary Project Thinking: Educational Thought and Practice.

[28]Vogel, I. (2012) "Review of the Use of 'theory of change' in International Development", Review Report, Department for International Development.

[29]Weijters, B., \& Baumgartner, H. (2012). Misresponse to reversed and negated items in surveys: A review. Journal of Marketing Research, 49(5), 737-747.

[30]Williams, F. (1974). The Identification of linguistic attitudes. International Journal of the Sociology of Language. 3(1) :21-32.

[31]World Bank. (2002). Education and HIV/AIDS: A Window of Hope. Washington D.C., World Bank. 